\title{
The Translation of Politeness Strategies Associated with Power Relation in Pramoedya's Cerita Calon Arang and The King, the Priest and the Witch
}

\author{
Deta Maria Sri Darta \\ deta.darta@staff.uksw.edu \\ English Department, Universitas Kristen Satya Wacana
}

\begin{abstract}
Translating is not as simple as changing a text form one language into another. It is more complicated, since it involves many aspects including linguistics and culture. Yet, translation is a helpfull aid when it comes to the International area. In literature, for example, a literary text owes a help from translation to be world wide acknowledged. This makes the duty of a translator becomes heavier, due to the burden of translating literary text that should be faithfull. This article gives example of the unfaithfull translation of a literary text from Indonesian into English, focusing on the translation of the politeness strategies found. The analysis showed that there are several politness strategies deleted or not translated, which made the translated text unfaithfull. While the translation strategies used resulted on different level of accuracy and acceptability.
\end{abstract}

Keywords: literary text, politeness strategies, translation techniques, translation quality

\section{Introduction}

In line with the definition of translation by Newmark - "rendering the meaning of a text into another language in the way that the author intended the text" (5) - we may think that it is simply saying something in other language. Yet, it comes up to be more complicated. It is more than just changing the language.

The relation between literary text and translation is quite close. Through translation, a literary text from a non English speaking country can travel around the world. Damrosch argues that "world literature is writing that gains in translation" (281). Meaning that the realm of world literature can only be entered by non English literary text if it is translated into English.
Thus, making translation as interdisiplinary studies. It does not only concern with transferring message or meaning from one language to another. Far beyond that, it also transfers the lingusitics aspect that the source language carries to the target language. If the translator fails to do this, there is a consequence should be payed. The translation might spoil or hail the master peace. An example is the analysis done by Katrin Bandel on the translation of Laskar Pelangi. She found that the translation version is being polished too much to fit the Target Culture. Now that The Rainbow Troops (the translated version) has become a world wide known, yet the one who should be addresed as a successfull writer has been hidden in grey area; is it the author or the translator? (249)

Translator should be faithfull. The problem with literary translation is that sometimes the translator feels free to adapt 
the story. The adaptation usually carries the translated version far from the original story. Although the translator argues that the adaptation is for the sake of the acceptance of the story, still the translator is not aware of the danger of the unfaithfull translation to literary text.

Some possible problems with the unfaithfull literary translation are related to the the interpretation of the texts. When a character is not described as in the original text, it will change the traits of the character, thus changing the identity of the character that was created thoughtfuly by the author. It will also affect the character development, if the reader analyzes it from the translated version. The different traits also create different dramatic effect that the readers get from reading the translated text compared to the original one. Another danger is that when it comes to local value that the literary text would like to convey, the readers will not get the real message that the author would like to convey.

This article would like to give a brief example of the unfaithfull translation of a literary text. Focusing on the speech acts comparison between the Indonesian literary text and its English translation. The speech acts analyzed are focused on the acts stated by characters in relation to power.

The analysis is done with the help of theory of speech acts, focusing on face threatening acts, and the politeness strategies. The types of speech act that people (in this case the characters) produce are related to the power they have in relation to other people (Culpeper 234). Culpeper also says that analysing the character's speech acts helps to reveal her/his characteristics (235). This topic falls under politeness theory, as politeness can be defined as minimizing confrontation in a discourse.

Politeness strategies are related to 'face' (reputation or prestige). This can be a positive face or negative face. Any action that hits the degree of someone's face is called face threatening acts (FTA). Brown and Levinson say that the degree of this FTA involves three variables: the social distance (D), the relative power $(\mathrm{P})$, and the absolute ranking $(\mathrm{R})$. This study focuses on the power relation variable, that is on the speech acts by characters having power and no power over the hearers.

The speech acts in this study are categorized into the politeness strategies proposed by Leech (206 - 207). The first maxim is tact maxim, meaning minimizing the cost to other. Second, generosity which minimizes the benefit to self. Then approbation maxim which means minimizing dispraise of others. The fourth maxim is modesty that minimizes the praise of self. Maxim number five is agreement which means minimizing disagreement between self and others, and the last is sympathy maxim that minimizes antipathy between self and others.

Since this study falls under translation studies, the translated version of the speech acts are also analyzed. The translation techniques used by the translator are studied based on the translation techniques proposed by Molina and Albir. In their article there are 18 techniques proposed (509 - 511). The translation techniques covers:

1. Adaptation, replacing a ST cultural item with one from the target culture

2. Amplification, giving details (information) that are not found in ST, including footnote.

3. Borrowing, taking a word or expression straight from another language, it can be pure (without any change) or naturalized

4. Calque, translating literaly from a foreign word or phrase (lexical or structural)

5. Compensation, introducing a ST element of information or stylistic effect in another place in the TT, because it cannot be reflected in the same place as in the ST.

6. Description, replacing a term or expression with a description of its form or/and function.

7. Discursive creation, establishing a temporary equivalence that is out of context.

8. Established equivalent, using a term or expression recognized as an equivalent in the TL. 
9. Generalization, using a more general or neutral term.

10. Linguistic amplification, adding linguistic elements.

11. Linguistic compression, synthesizing linguistic elements in the TT.

12. Literal translation, translating a word or an expression word for word.

13. Modulation, changing the point of view, focus or cognitive category in relation to the ST (both lexical and structural).

14. Particularization, using a more precise or concrete term.

15. Reduction, shortening a ST information item in the TT.

16. Substitution (linguistic, paralinguistic), changing linguistic elements for paralinguistic elements (intonation, gestures) or vice versa.

17. Transposition, changing a grammatical category.

18. Variation, changing linguistic or paralinguistic elements (intonation, gestures) that affect aspects of linguistic variation: textual tone, style, social dialect, geographical dialect.

The translated version is also analyzed its quality by the means of its accuracy and acceptability. This study uses the translation quality assessment proposed by Nababan et al in the article Pengembangan Model Penilaian Kualitas Terjemahan (39 - 57). In the article, there are three variables used to determine the quality of translation, namely accuracy, acceptability, and readability. Each has its own categories, scores and parameters. Although there are three variables proposed in the article, this study only focuses on two variables, accuracy and acceptability.

\section{Methods}

a. The object is the politeness strategies used by some characters in Calon Arang based on the power relation they have and the translation of the utterances in the English version.

b. The data will be in the form of utterances taken from both texts, the source and target texts. The utterances are spoken by the characters that are limited to the power relation. c. The procedure:

1. Finding the utterances based on power relation with the variables of $+P+D+R$, $+\mathrm{P}-\mathrm{D}+\mathrm{R},-\mathrm{P}+\mathrm{D}-\mathrm{R},-\mathrm{P}-\mathrm{D}-\mathrm{R}$

2. Categorize the utterances into the politeness strategies used.

3. Find the utterances translations in the English version

4. Examine the category of politeness strategies used in the English version

5. Analyze the translation techniques used

6. Analyze the quality of translation: accuracy and acceptability

7. Relate the quality with the techniques used

\section{Finding and Discussion}

The finding and discussion is divided into two parts, namely politeness strategies and the translation techniques, and the quality of its translation.

\section{Politeness strategies and the translation techniques}

The speech acts selected to analyze are those spoken by the characters related to power, thus only 4 combinations of variables. The data are taken from Cerita Calon Arang (CCA) and its translation The King, the Priest, the Witch (KPW). Then in each combination of speech acts found are analysed using the theory of politeness strategies as well as the translated version. The analysis then is followed by the translation techniques used by the translator.

\section{1. $+P+D+R$}

The examples to the first variable are utterances spoken by a teacher to his or her students and a king to his subbordinates.

\section{A teacher to his/her students}

Having the power, distance and ranking above her students, Calon Arang shouted to his students when they gave opinion that was not pleased her: "Diam, kalian!" (CCA, 40). In this utterance, Calon Arang violated the 
aggreement maxim. Instead of respecting her student's opinion, Calon Arang disregarded his opinion by telling him to shut up.

Then in the English version, it is not translated. The translator, Willem Samuels did not translate this utterance.

The second example is taken from the utterance spoken by Empu Baradah to his students. He asked his students to build a house for his daughter: "Anakku semua," ..., "karena anakku Wedawati tak mau pulang dari kuburan, aku minta agar engkau semua dengan rela hati sudi mendirikan rumah di pekarangan kuburan untuk anakku." (CCA, 65). Here, Empu Baradah used tact maxim to softly demand his students to build a house for his daugther. He called his students 'anakku' (my children) to reduce the feeling of being forced to do a task. He also polished his sentence with the phrase 'rela hati sudi' which indicates that he wanted his students to feel unburden. Although he knew that he can directly give order.

When analyzed in the English version, the utterance is translated into

"My children, ..., because my daugther Wedawati does not want to return home from the cemetery, I ask for your help in building a home for her within the cemetery ground." (KPW, 78)

The phrase 'my children' is still maintained, but the phrase 'rela hati sudi' is translated into 'help'. Thus the technique used is generalization. The translated utterance is still categorized under tact maxim although the degree is lessen.

\section{- $\quad$ A king to his subordinates}

"Penyakit ini harus dilenyapkan. Kalau tidak bisa, setidak-tidaknya harus dibatasi. Kirimkan balatentara ke dusun Girah. Tangkap Calon Arang. Kalau melawan, bunuh dia bersama muridmuridnya." (CCA, 30)

The utterances above was spoken by King Erlangga to his Prime Minister, after hearing the report about the plague spreaded by Calon Arang. The King violated the tact maxim by directly giving order to his Prime Minister.

The English version still violated the tact maxim, but the degree is lessen by changing the imperative "Kirimkan balatentara ke dusun Girah. Tangkap Calon Arang" into statement "I will send troops to the village of Girah to arrest Calon Arang" (KPW, 42). The translation technique used is transposition.

\section{2. $+P-D+R$}

In this variable, the examples are taken from the utterances spoken by a husband to his wife, a father to his daugther, a mother to her daughter, and Goddess to her worshiper.

\section{A husband to his wife}

The first example here is taken from the utterance spoken by Empu Bahula to Ratna Manggali, after knowing that Calon Arang own a sacred book that help her to spread tha plague:

"Ratna Manggali, adikku! Ingin benar aku melihat kitab yang bertuah itu. Ingin aku tahu apakah isinya. Maukah engkau menolong aku?" (CCA, 73)

"Kalau ibu sedang tidur, cobalah ambilkan kitab itu. Aku ingin tahu isinya. Engkau mau, bukan?" (CCA, 74)

The utterance used tact maxim, by calling his wife 'adikku' (little sister), Empu Bahula reduced the burden of his wife to help him. However, this phrase is deleted, ommited or not translated into English, thus making the translation violating the tact maxim since the request was directly stated by Empu Bahula to his wife.

\section{A father to his daugther}

"Wati! Wati, anakku manis, di mana engkau? ..." (CCA, 62)

"Mengapa engkau hendak menyedihkan hati ayahmu, Wati?" (CCA, 64) 
The two sentences above were spoken by Empu Baradah to his daughter, Wedawati. The first sentence used approbation maxim with the phrase 'anakku manis' (my sweety). While the second sentence violated the sympathy maxim since Empu Baradah only concerned with his own feeling.

In the translated version, the first sentence was ommited. While the second is translated into a more general sentence: "Why do you want to make me sad?" (KPW, 77). This can fall into the category of violating sympathy maxim because Empu Baradah only still concerned with his feeling.

\section{A mother to her daugther}

Compared to the utterances spoken by a father to her daugther, this utterance spoken by Calon Arang to her daughter tends to be more harsh: "Diam, kau anak bayi! Jangan bertanya-tanya." (CCA, 37). It was a reply Ratna Manggali got when she asked her mother where she will go. Calon Arang threatened Ratna Manggali's face by calling her a baby. She violated approbation maxim. This made Ratna Manggali affraid of her own mother. This utterance was deleted or ommited in the translated version.

\section{Goddess to her worshiper}

Being worshiped by her followers made Dewi Durga own power, but she put herself in a close distance to her followers, especially Calon Arang. She used 'anakku' (my child) to call Calon Arang as seen from the utterances below.

“Calon Arang anakku," (CCA, 13)

"Katakan maksudmu, anakku." (CCA, 14)

"Jangan kau khawatirkan sesuatu apapun. Aku izinkan kau membangkitkan penyakit. Dan banyak sekali orang akan mati karenanya." (CCA, 14)

The utterances used approbation maxim. This strategy is used to make her followers worship her more and become dependant to her.
The English version of those utterances maintains the approbation maxim by using the phrase 'my child', while the technique used is adaptation especially in the third utterance:

“Calon Arang, my child," (KWP, 18)

"What is it you would say?" (KWP, 19)

"Be still your worried heart, my child. I hereby grant you permission to send forth a plague to attack your enemy." (KWP, 19)

\section{3. $-\mathbf{P}+\mathbf{D}-\mathbf{R}$}

The examples to the third variable are taken from the utterances spoken by Prime Minister to King Erlangga, Lendi to Calon Arang, and Calon Arang to Dewi Durga.

\section{Subordinates to their King}

When Prime Minister reported the plague to King Erlangga, he used approbation maxim since he put the King as having higher status, even when he knew things more than the King: "Ampun Baginda," sembahnya. "Patik menghaturkan periksa, bahwa janda dari Girahlah yang menerbitkan segala keonaran dan bencana ini." (CCA, 29)

That approbation maxim was translated into: "Based on my investigations, Your Highness, it is a woman from Girah, a widow with one child, who is the cause of all this chaos and calamity." (KPW, 41). Here the translation technique used is established equivalent to maintain the approbation maxim.

\section{Students to their teacher}

Having considered to be a subordinate of his teacher, Lendi complimented Calon Arang by calling her 'kanjeng Nyai'. This nickname showed that Lendi appreciated his teacher since 'kanjeng' means having the highest rank within the community or group. Thus, he used the approbation maxim.

"Apakah yang kanjeng Nyai pikirkan?"
(CCA, 39)
"Kanjeng Nyai! Ijinkanlah hamba
mengemukakan pendapat." (CCA, 40)


Using particularization technique, the first utterance above was translated into: "What is it you are thinking, Teacher?" (KPW, 54). It is still an approbation maxim, but the intensity is lower since the word 'kanjeng' was not translated. While the second utterance was not translated or ommited.

\section{Worshiper to her Goddess}

Calon Arang, in the purpose of asking help from Dewi Durga to fullfil her need, used approbation and modesty maxim by putting Dewi Durga in the higher rank and herself as the lowest, as seen in the two utterances below:

"Izinkanlah hambamu memohon kasih dari Paduka Dewi." (CCA, 14)

"Ya, Paduka Dewi, berilah hamba izin untuk membangkitkan penyakit buat menumpas orang banyak-banyak." (CCA, 14)

Calon Arang even used the phrase 'Dewi pujaan hamba' (my idol goddess) to address Dewi Durga. She did it to exaggerate her admiration to Dewi Durga: "Ampun, Dewi pujaan hamba. Ijinkanlah hamba membuat penyakit besar-besaran. ..." (CCA, 44). This utterance used approbation maxim.

It was translated into "Forgive thy humble servant, dear Durga, and permit me to spread the illness farther. ..." (KWP, 60) by maintaining approbation and modesty maxim with the use of established equivalent.

\section{4. $-P-D-R$}

The examples of the variable are taken from the utterances spoken by the wife of Empu Baradah addressing the Empu himself and Wedawati addressing her father, Empu Baradah.

\section{A wife to her husband}

"Tuanku Sang empu, sepergi tuanku mengajar di pertapaan Wisauka, ananda Wedawati bertengkar dengan adiknya." (CCA, 48)

The utterance above was said by Empu Baradah's wife when informing him that
Wedawati fleed from home. A a wife in Javanesse culture, she put herself in lower position to his husband and used modesty maxim by addressing him as 'tuanku sang empu'.

Using the technique of variation the modesty maxim is no longer there in the English translation: "You're probably wondering where Wediawati is. All I can say is that she's gone. She got into a fight with her brother and became so angry she left home." (KWP, 74). The culture sense in the original utterance is failed to be carried to its English translation.

\section{A daugther to her father/mother}

Meanwhile, the modesty maxim in the utterance spoken by Wedawati to her father: "Ayahanda, "... "hamba sudah berniat tinggal di kuburan ini. Hamba tidak ingin pulang." (CCA, 64 ) is carried to its English translation with the use of variation technique:

"That's not what I want to do, Father," said Wedawati politely. "I want to live here, in this cemetery. I now know what I must do". (KWP, 77)

Although the word 'ayahanda' and 'hamba' which signaled the modesty maxim in the original text were not translated into English, still the English version is considered having the modesty maxim, by having the capitalized the initial letter of the word 'Father'. However, the english version also violated the tact maxim since Wedawati gave high value to what she wanted.

To make it easier to read, the finding and discussion on politeness strategies and translation techniques above can be summed up into the table below: 


\begin{tabular}{|c|c|c|c|c|}
\hline No & Variables & $\begin{array}{l}\text { Politeness strategies } \\
\text { found in the Source Text }\end{array}$ & $\begin{array}{l}\text { Politeness strategies } \\
\text { found in the Target Text }\end{array}$ & $\begin{array}{c}\text { Translation Technique } \\
\text { used }\end{array}$ \\
\hline 1 & \multirow{3}{*}{$+P+D+R$} & $\begin{array}{l}\text { violating agreement } \\
\text { maxim }\end{array}$ & - & $(-)$ Not translated \\
\hline 2 & & tact maxim & tact maxim & Generalization \\
\hline 3 & & violating tact maxim & violating tact maxim & Transposition \\
\hline 4 & \multirow{5}{*}{$+\mathrm{P}-\mathrm{D}+\mathrm{R}$} & tact maxim & violating tact maxim & $(-)$ Not translated \\
\hline 5 & & approbation maxim & - & $(-)$ Not translated \\
\hline 6 & & violating sympathy maxim & violating sympathy maxim & Generalization \\
\hline 7 & & $\begin{array}{l}\text { violating approbation } \\
\text { maxim }\end{array}$ & - & $(-)$ Not translated \\
\hline 8 & & approbation maxim & approbation maxim & Adaptation \\
\hline 9 & \multirow{4}{*}{$-P+D-R$} & approbation maxim & approbation maxim & established equivalent \\
\hline 10 & & approbation maxim & approbation maxim & Particularization \\
\hline 11 & & approbation maxim & - & $(-)$ Not translated \\
\hline 12 & & $\begin{array}{l}\text { approbation and modesty } \\
\text { maxim }\end{array}$ & $\begin{array}{l}\text { approbation and modesty } \\
\text { maxim }\end{array}$ & established equivalent \\
\hline 13 & \multirow[b]{2}{*}{-P-D-R } & modesty maxim & violating modesty maxim & Variation \\
\hline 14 & & modesty maxim & $\begin{array}{l}\text { modesty and violating tact } \\
\text { maxim }\end{array}$ & Variation \\
\hline
\end{tabular}

To translate the speech acts containing politeness strategies, the translator used six translation techniques. He also decided not to translate several speech acts. His decision of using certain techniques and deleting the speech acts from the translated version resulted on the changes of the category of the politeness strategies used. From the table presented above, a politeness strategy was translated into the same strategy by using several translation techniques, they are generalization, adaptation, transposition, established equivalent, and particularization. Meantime, when the technique of variation was used, the category of politeness strategies changed.

\section{The Quality of Its Translation}

The result of the translation can be assessed in terms of its accuracy and acceptability. Each variable is assessed and measured its score to determine its quality by using the parameters proposed by Nababan et al. The accuracy is measured whether the meaning of word, phrase, clause, sentence or text is translated accurately without any distortion. While the acceptability is measured whether the translation result is natural, familiar and according to the correct norms. Each instrument has 3 level of scoring, 3 for the highest score and 1 for the lowest.

From the table presented below, it can be infered that the accurate translation occured when the translator managed to translate a politeness strategy into the same category using techniques of transposition, adaptation, established equivalent, and particularization.

While in the acceptability category, the used of 6 translation techniques mentioned before resulted on the highest score. This is because the different culture between Indonesia and Western, where in Indonesia, especially in Javanesse culture, we have levels of politeness stated by addressing system that can not be found in English. For example, in conventional Javanesse culture, a wife will put herself into a lower position to her husband especially when speaking directly to him. She will address her husband as "tuanku" (my lord). It is because in Javanesse culture a household is like a Kingdom, where husband serves as a king, especially when the husband 
has a certain social status (a priest for example). This way of addressing husband can not be translated into English, since it is awkward. In Western culture the position of husband and wife is considered equal and the relation is more romantic then having gradation.
The assessment of the translation quality is sum up in the following table:

\begin{tabular}{|c|c|c|c|c|c|c|}
\hline \multirow[t]{2}{*}{ No } & \multirow[t]{2}{*}{ Variables } & \multirow{2}{*}{$\begin{array}{c}\text { Politeness } \\
\text { strategies found } \\
\text { in the Source Text }\end{array}$} & \multirow{2}{*}{$\begin{array}{c}\text { Politeness } \\
\text { strategies found } \\
\text { in the Target Text }\end{array}$} & \multirow[t]{2}{*}{$\begin{array}{c}\text { Translation } \\
\text { Technique used }\end{array}$} & \multicolumn{2}{|c|}{ Quality } \\
\hline & & & & & Accuracy & $\begin{array}{l}\text { Accept } \\
\text { ability }\end{array}$ \\
\hline 1 & \multirow{3}{*}{$+\mathrm{P}+\mathrm{D}+\mathrm{R}$} & $\begin{array}{c}\text { violating } \\
\text { agreement maxim }\end{array}$ & - & (-) Not translated & 1 & 1 \\
\hline 2 & & tact maxim & tact maxim & Generalization & 2 & 2 \\
\hline 3 & & $\begin{array}{l}\text { violating tact } \\
\text { maxim }\end{array}$ & $\begin{array}{l}\text { violating tact } \\
\text { maxim }\end{array}$ & Transposition & 3 & 3 \\
\hline 4 & \multirow{5}{*}{$+P-D+R$} & tact maxim & $\begin{array}{l}\text { violating tact } \\
\text { maxim }\end{array}$ & (-) Not translated & 1 & 1 \\
\hline 5 & & $\begin{array}{l}\text { approbation } \\
\text { maxim }\end{array}$ & - & (-) Not translated & 1 & 1 \\
\hline 6 & & $\begin{array}{l}\text { violating sympathy } \\
\text { maxim }\end{array}$ & $\begin{array}{l}\text { violating sympathy } \\
\text { maxim }\end{array}$ & Generalization & 2 & 2 \\
\hline 7 & & $\begin{array}{c}\text { violating } \\
\text { approbation } \\
\text { maxim } \\
\end{array}$ & - & (-) Not translated & 1 & 1 \\
\hline 8 & & $\begin{array}{l}\text { approbation } \\
\text { maxim }\end{array}$ & $\begin{array}{c}\text { approbation } \\
\text { maxim }\end{array}$ & Adaptation & 3 & 3 \\
\hline 9 & \multirow{4}{*}{$-P+D-R$} & $\begin{array}{l}\text { approbation } \\
\text { maxim }\end{array}$ & $\begin{array}{l}\text { approbation } \\
\text { maxim }\end{array}$ & $\begin{array}{l}\text { established } \\
\text { equivalent }\end{array}$ & 3 & 3 \\
\hline 10 & & $\begin{array}{l}\text { approbation } \\
\text { maxim }\end{array}$ & $\begin{array}{l}\text { approbation } \\
\text { maxim }\end{array}$ & Particularization & 3 & 3 \\
\hline 11 & & $\begin{array}{l}\text { approbation } \\
\text { maxim }\end{array}$ & - & (-) Not translated & 1 & 1 \\
\hline 12 & & $\begin{array}{l}\text { approbation and } \\
\text { modesty maxim }\end{array}$ & $\begin{array}{l}\text { approbation and } \\
\text { modesty maxim }\end{array}$ & $\begin{array}{c}\text { established } \\
\text { equivalent }\end{array}$ & 3 & 3 \\
\hline 13 & \multirow[b]{2}{*}{-P-D-R } & modesty maxim & $\begin{array}{l}\text { violating modesty } \\
\text { maxim }\end{array}$ & Variation & 2 & 3 \\
\hline 14 & & modesty maxim & $\begin{array}{l}\text { modesty and } \\
\text { violating tact } \\
\text { maxim }\end{array}$ & Variation & 2 & 3 \\
\hline
\end{tabular}

\section{Conclusion}

Although translating literary text, translator should maintain faithfull to the original text. Translating speech acts is not easy; a certain politeness strategy should be translated into the same strategy, which is not always easy. Based on the analysis done, some translation techniques are suitable to translate politeness strategies. However, when the translator decided not to translate because he could not find the equal version in the target language, the translated version become unfaithfull, thus the quality is low. Speech acts, 
especially associated with power relation between speakers, are culturally bounded. Thus, translating them into other languages is complicated, since it involves the understanding of source and target culture.

\section{References}

Baker, Mona. In Other Words. Routledge, 2011.

Bandel, Katrin. Sastra Nasionalisme Pascakolinialitas. Pustaha hariara, 2013.

Culpeper, Jonathan. Language \& Characterization. Pearson Education, 2014.

Damrosch, David. What is World Literature? Princeton University Press, 2003.

Fahrurrozi, Fahrurrozi \& Andri Wicaksono. Sekilas tentang Bahasa Indonesia. Garudhawaca, 2016.

Leech, Geoffrey. The Principle of Pragmatics. Longman, 1983. . Prinsip-prinsip Pragmatik. Translator: M.D.D. Oka. UI-Press, 2015.

Molina, L \& Hurtado Albir, A. "Translation Techniques Revisited: A Dynamic and Functionalist Approach." Meta, 47(4). Doi: 10.7202/008033ar. 2002, p. 498512.

Nababan, M., Nuraeni, A., dan Sumardiono. "Model Penilaian Kualitas Terjemahan". Jurnal Kajian Linguistik dan Sastra, 24, 1. 2012, p. 39-57.

Newmark, Peter. A Textbook of Translation. Pearson Education, 2001.

Nida, E \& Charles Taber. The Theory and Practice of Translation. Brill, 2003.

Toer, Pramoedya A. Cerita Calon Arang. Lentera Dipantara, 2006.
. The King, the Priest, the Witch.

Translator: Willem Samuels. Equinox Publishing (Asi) Pte.Ltd, 2002. 